\title{
Optimization Of Distributed Hybrid Renewable Energy Resources In Power Network: Study Of Madangho---Escravos
}

\author{
Omorogiuwa Eseosa, Ekiyor Martin Thompson
}

\begin{abstract}
In Nigeria, major urban communities are supplied electricity through conventional grid systems, leaving majority in remote rural communities with little or no supply. Hence, diesel and petrol generators become means of generating electricity for these small remote villages for their livelihood and survival. This has resulted to gradual environmental change; global warming because of large fossil fuel emissions etc. Renewable Energy (RE) is abundant in nature and can provide unlimited clean energy to run the day-to-day electricity services in order to enhance socio-economic life of these rural dwellers. The research study is Madangho-Escravos, a remote rural community located at the coastline of Atlantic Ocean, in Niger Delta region of Nigeria. Available RE sources in Madangho are solar, wind, tidal and biomass. Distributed Hybrid Renewable Energy Sources (DHRES) comprising of Solar, wind and diesel generator were modeled using HOMER Software. Solar irradiance and wind speed data for Madangho-Escravos were collected from NIMET Osubi Airport. DHRES optimization indicated its feasibility and viability with low (Net Present Cost) NPC, Operating and Maintenance cost, and Cost of Electricity (COE) compared to conventional grid system.
\end{abstract}

\section{Index Terms- DHRES,HOMER,NIMET,NIGERIA,NPC}

\section{INTRODUCTION}

Due to insufficient power supply in most developing and under-developed countries especially in Africa, Renewable Energy Sources (RES) are gradually becoming alternative means of clean power supply for urban and most rural areas. Nigeria has potentials of generating electricity that could power the whole of West Africa [1] but not self-sufficient in generation, transmission and distribution. Nigeria with population of 180 million people is largely powered by depleting hydrocarbon resources and hydropower, which can also be used as alternative RES. Presently, Nigeria is able to generate only $3864.4 \mathrm{MW}$ peak [2] which is $64 \%$ installed capacity of $6000 \mathrm{MW}$ because most of the National grid facilities are rarely or poorly maintained. Due to very high-energy losses between $30 \%$ - 35\% in transmission network, demand for available electricity is far greater than energy supply [3]. The country has an electric power density of $33 \mathrm{~W}$ per person, which is perhaps one of the lowest in Africa. Considering this fact, there is huge energy market in Nigeria because of the gap between current energy production and demand for energy. The sustainable option is to meet this demand with available renewable energy mix to reduce pollution, which hydropower is on the front burner in

Omorogiuwa Eseosa, Electrical/Electronic Department, University of Port Harcourt, Choba, Nigeria, 08035150986.

Ekiyor Martin Thompson, Electrical/Electronic Department, University of Port Harcourt, Choba, Nigeria, 08035150986 present-day Nigeria [4]. Major parts of Nigeria's population are rural dwellers and are not connected to conventional grid either due to difficult terrain or bad roads [3]. However, rural communities have sparse population and low load density with very short periods of peak loads. Over the years, conventional means of power generation using fossil fuel is besieged by lack of political will to develop power sector in Nigeria. Technical and socio-economic challenges such as insufficient power generation capacity, low power distribution rate to customers, lack of capital for investment, limited access to infrastructure, inefficient usage of power generated, ineffective regulation, insufficient transmission and distribution facilities, high technical losses and vandalism [5] face present-day power sector. Preliminary studies indicate some major challenges that hinder massive deployment of renewables in Nigeria and Africa at large. These include, cost, technology, willingness of government to adopt and implement hybrid Renewable Energy (RE) systems in the country. This paper therefore focuses on Optimization of Distributed Hybrid Renewable Energy Resources (DHRES) such as solar, wind, hydro, biomass, biogas, fuel cells etc, abundant in Nigeria. HOMER software developed by National Renewable Energy Laboratory (NREL).[6] is used in this study to design, simulate and analyze both technical and economic feasibility of implementing DHRES in Madangho community and further analyze the emissions from the power network. The study area location is Madangho community in Escravos which is a coastal oil producing community located on latitude $5.600542,\left(5^{\circ} 36^{\prime} 02.0^{\prime \prime} \mathrm{N}\right)$ and longitude $5.214818\left(5^{\circ} 12^{\prime} 53.3^{\prime \prime E}\right)$ of about $75 \mathrm{~km}$ (3-4 hours' boat drive) from Warri, Delta State. Presently, Madangho is powered by Caterpillar 400kVA $(320 \mathrm{~kW})$ D3306 diesel generator for $12 \mathrm{hrs}$ each day from $7 \mathrm{pm}$ to $7 \mathrm{am}$, while Shell Petroleum Development Company (SPDC) maintains and manages the diesel generator as part of its Cooperate-Social Responsibility (CSR). There is no direct gas pipeline passing through Madangho community as the closest is ELP (Escravos-to-Lagos Pipeline) located about $1 \mathrm{~km}$ from the community with pressure of 90 bars. Thus, the gas manifold may require some modifications before it can be used for power generation, if there is political will to embark on such project.

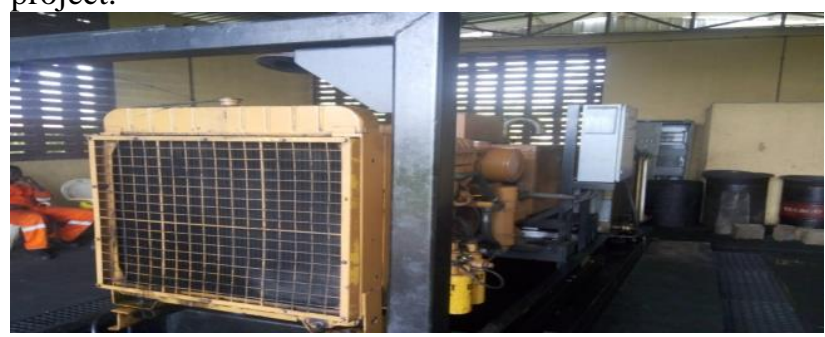

Figure 1.0: Madangho Diesel Generator (CAT D3306) 
The cost of transportation of diesel through river and maintenance spares for running the existing CAT generator is enormous considering the frequency, terrain and present security situation of the Niger Delta. However, Madangho Community is endowed with multiple RE resources that need to be harnessed and optimized to meet the community electricity demand.

\section{LITERATURE REVIEW}

In Nigeria, conventional grid power supply is perhaps the main source of electricity in urban and some rural areas. With a population of 182 million people, the total installed power capacity is $6000 \mathrm{MW}$, which cannot evacuate completely through the existing national grid power network. The current generating capacity is $4000 \mathrm{MW}$, meaning majority of the country's population does not have access to electricity supply [7] yet it is richly endowed with enormous amount of energy resources that includes crude oil, natural gas, coal, and tar sands that is sufficient for electricity production. The country continuously suffers greatly from incessant power outages and insufficient power generation to meet her energy demand. Most of the remote rural communities are not connected to conventional utility grid system, even when major population of the country resides in rural areas; some communities have local diesel generators that run to keep daily business activities while others run personal diesel or petrol generators [3]. The total cost of buying diesel daily is a huge challenge for rural dwellers considering their low cash flow and small business activities. DHRES when optimized can reliably and efficiently generate adequate electricity for most rural dwellers [6].

In the last few decades, there is a paradigm shift towards the use of renewable energy because of the unstable supply of nuclear, fossil fuel and natural gas. In the world today, there is great demand for energy, according to World Bank and International Energy Agency (IEA) - in the next 40 years the world will require double energy installed capacity. In addition, an estimate of 1.3 billion people living far away from urban cities in developing countries is not able to access the conventional grid system. Thus, choice of renewable energy becomes an economic alternative for $80 \%$ of the world's rural dwellers who are far away from conventional grid and whose major source of energy is local firewood [8]. Renewable energy is gradually becoming the world's panacea for tackling lingering problem of global warming or climate change. Because of the use of fossil fuel in conventional generation of energy, non-ecological friendly gases like $\mathrm{CO}_{2}$, $\mathrm{SO}_{2}$ and $\mathrm{NO}_{\mathrm{x}}$ negatively affect the environment, resulting in global warming [9]. According to the IEA (International Energy Agency) report, 100Gt (Gigatons) of $\mathrm{CO}_{2}$ emission during the period of 2008 to 2050 could be prevented using renewable energy technology especially Solar-PV [10].

The sun radiates energy in all directions uniformly in close harmony with Plank's blackbody radiation equation. Energy density per unit area (as function of wavelength $K$ ) at the surface of the sun is

$w_{K}=\frac{2 \pi h c^{2} K^{-5}}{e^{\left(\frac{h c}{\mathrm{KkT}}\right)}-1},(\mathrm{~W} / \mathrm{m} 2 /$ unit wavelength in meters $)$

Where: Plank's constant $\mathrm{h}=6.63 \times 10^{-34} \mathrm{Ws}^{2}$, Speed of light in vacuum $\mathrm{c}=3.00 \times 108 \mathrm{~m} / \mathrm{s}$, Boltzmann's constant $\mathrm{k}=1.38 \mathrm{x}$ $10^{-23} \mathrm{~J} / \mathrm{K}$ and $\mathrm{K}$ is absolute temperature of blackbody in Kelvin (where $0 \mathrm{~K}=-273.16^{\circ} \mathrm{C}$ )
Global Horizontal Irradiance (GHI), which is the total horizontal solar radiation from the sun, consists of Direct Normal Irradiance (DNI), Diffuse Irradiance and a function of the solar zenith angle [11]. The DNI is the solar beam radiation to a plane perpendicular to sun's direction, the expression in equation 2 gives GHI value:

$G H I=$ Diffuse + DNI $x \operatorname{Cos}(z)$

Where $z$ is the solar zenith angle

The most promising renewable energy resource in Nigeria is solar energy resource; the country has an average $1.804 \times 10^{15}$ $\mathrm{kWh}$ of incident solar energy yearly [3]. Moreover, annual average irradiance varies from about $7 \mathrm{kWh} / \mathrm{m}^{2} /$ day along the far north semi-arid area to the coastal area of about $3.5 \mathrm{~kW} / \mathrm{m}^{2} /$ day. The average sunshine is about 6 hours per day, which gives $5.5 \mathrm{kWh} / \mathrm{m}^{2} /$ day as average solar irradiation level [12]. In the Warri (Niger Delta) a city very close to the research location and Madangho- Escravos the research location, the annual average $\mathrm{GHI}$ is $4.53 \mathrm{kWh} / \mathrm{m}^{2} /$ day and [13] which is enough for solar- electric generators.

The current from PV panel is given by:

$I_{p v}=I_{p h}-I_{p}\left[e^{\frac{q\left(v_{p v}+i_{p v} R_{s}\right)}{\eta \cdot k \cdot T}}\right]-\frac{v_{p v}+i_{p v} \cdot R_{s}}{R_{s h}}$

Where $i_{p v}$ and $v_{p v}$ are photovoltaic cells terminal output current and voltage respectively

$I_{p h}=$ photocurrent $I_{p}=$ output current of series resistor, $R_{s}=$ series resistor; $R_{s h}=$ shunt resistor, $\mathrm{q}=$ electron charge, $\eta=$ quality factor of $\mathrm{P}-\mathrm{N}$ junction; $\mathrm{T}=$ ambient temperature, $\mathrm{k}=$ Boltzmann constant.

Efficiency of the PV is the ratio of actual dc output with generated maximum power of the PV panel at maximum irradiance level of $1000 \mathrm{~W} / \mathrm{m}^{2}[2,11]$.

\section{A. Distributed Energy Resources (DER)}

According to Electric Power Research Institute (EPRI), Distributed Energy Resources (DER) are smaller power sources that can combine to provide power required to meet regular load demand. DER or Distributed Generation (DG) comprises of units of small-scale generators that are within the range of $3 \mathrm{~kW}-10 \mathrm{MW}$ from many energy sources used to provide power close to consumers. With the traditional electric power system efficiency is low, there is high power loss through transmission and distribution network, and not environmentally friendly. Some benefits derived from DER are voltage improvement, reduction in power loss and $\mathrm{CO}_{2}$ emission, increased reliability and availability, etc.

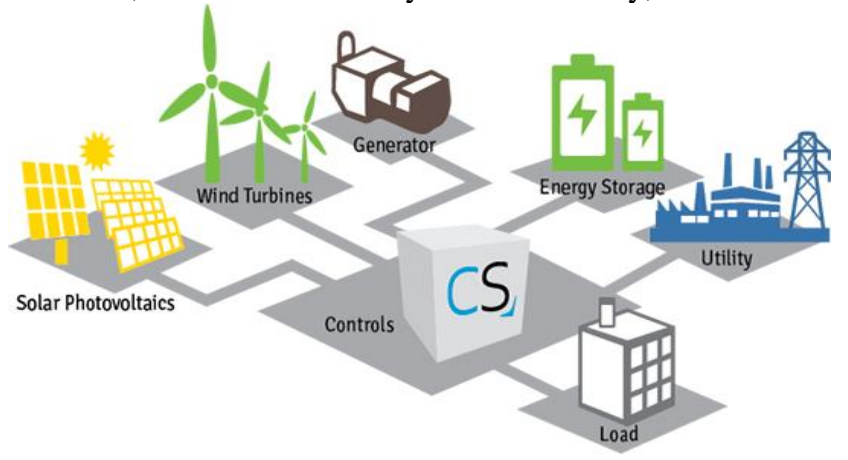

Figure 2.0: Distributed Renewable System

The Fig 2.0 illustrates traditional centralized system of power network where renewable hybrid generation is distributed, 
and storage system kept in different location to meet load demand.

\section{METHODOLOGY}

This study uses HOMER software [14] to model and simulate DHRES in Madangho community. The proposed DHRES comprises of Photovoltaic (PV) array, wind turbines, battery bank, an existing diesel generator (Cat.D3306) and power converter. The diesel and battery bank are added to the system for backup purposes. The design is an off-grid system, due to absence of nearby conventional grid system. Already available rural power distribution system is used. The village load is assessed through power parameter logging from an existing diesel generation; seasonal load variation is considered, and average peak load are identified which are fed as inputs to the HOMER Software. Wind and solar radiation resources are collected from NIMET database. Sensitivity data are used in component and cost analyses for optimization purpose. The life-time reliability is computed to be 20 years. Cost of Energy $(\mathrm{CoE})$ is also determined. Figure 3.0 shows the framework.

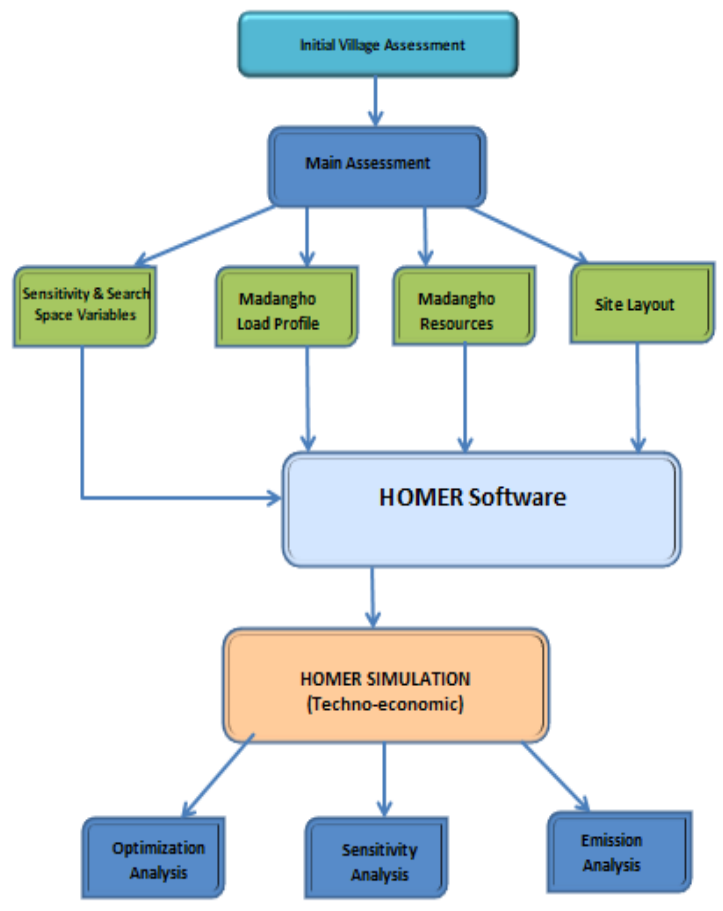

Figure 3.0: Framework for the study

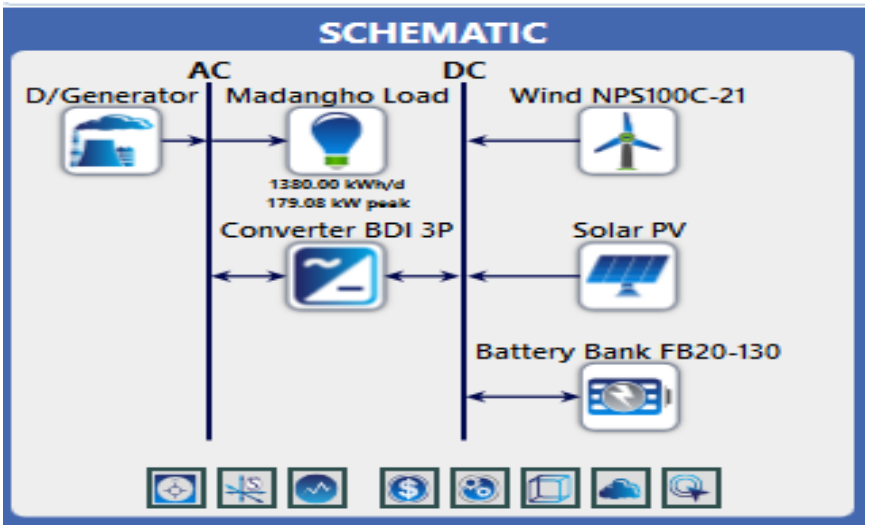

Figure 4.0: HOMER Design of Selected DHRES

\section{SYSTEM MODELING}

A small remote village Madangho is selected for the off-grid study; it is located in Escravos, coastal region in Warri South Local Government in Delta state. The closest grid system is located in Warri a city about $100 \mathrm{~km}$ away from Madangho by boat or flight (helicopter); there are no roads linking the research location with the city. The three main principles HOMER software uses to determine the optimal sizing and operational strategy are simulation, optimization and sensitivity analysis as depicted in Figure 3.0. HOMER simulates the designed system based on chosen components; it performs energy balance calculations with respect to system configuration whilst considering various numbers of components chosen for the analysis. In this case study, wind turbine, solar PV, diesel generator, battery and converter are used as components for the analysis. HOMER simulates the best feasible configuration of the designed system which can efficiently serve the load demand. Optimization process is done after simulating complete possible solution of DHRES configuration. HOMER displays various combinations possible based on Total Net Present Cost (TNPC) in ascending order leaving the lowest at top of the list. Sensitivity analysis is done by repeating the optimization process for every inputted sensitivity value like various values for wind speed, solar irradiance and the price of fuel (diesel). Table 1.0 shows detailed description of the area under study.

Table 1.0: Madangho Village Profile

\begin{tabular}{|c|c|c|}
\hline Particulars & Details & Remark \\
\hline Village name & Madangho & \\
\hline Latitude & $503602.00 \mathrm{~N}(5.600542)$ & \\
\hline Longitude & $501253,3 \mathrm{z}=(5.214818)$ & \\
\hline Sub-district & Escravos & Area \\
\hline District & Warni-South West & Local Government Area \\
\hline State & Delta & \\
\hline Country & Nigeria & \\
\hline Elevation (meters) & 21 & \\
\hline Terrain & Swampy \& harsh & \\
\hline Water well & 1 & \\
\hline Grid electricity & 0 & \\
\hline Number of Households & 72 & \\
\hline Total Population & 2845 & Community Record \\
\hline Education facility & 2 & (1 government, 1 private) \\
\hline Major Occupation & Fishing \& Farming & \\
\hline Medical Facility & 1 & Primary Health Centre \\
\hline Police Station & 1 & \\
\hline Guest House & 3 & Small Hotel \\
\hline Churches & 4 & \\
\hline
\end{tabular}

\section{RESOURCE ASSESSMENT}

In this case study, solar PV, wind and diesel generator are used as resources; Solar resource was taken from Nigeria Meteorological Agency (NIMET) [15] for Madangho on Latitude $5^{\circ} 36^{\prime} 02.0^{\prime} \mathrm{N}(5.600542)$ and Longitude $5^{\circ} 12^{\prime} 53.3^{\prime \prime} \mathrm{E}$ (5.214818), annual average irradiance was found to be $4.33 \mathrm{kWh} / \mathrm{m}^{2} /$ day and average clearness index of $\mathbf{0 . 4 3 8}$ as shown in Figure 5.0 


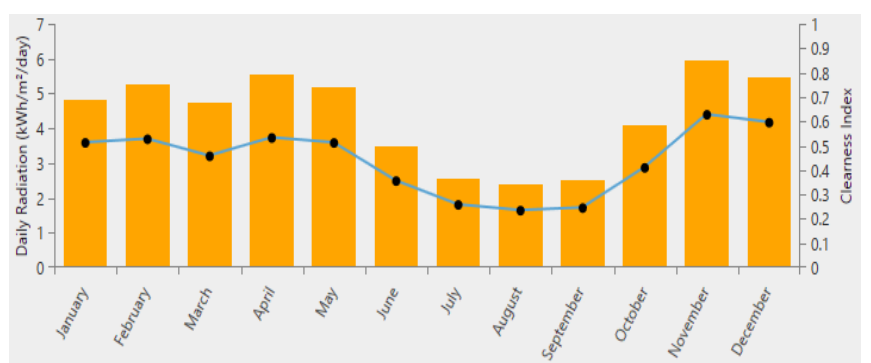

Figure 5.0: Monthly Average Solar GHI for Madangho

Madangho -wind resources data was taken from NIMET from an average of six years, based on the latitude and longitude of the research location with anemometer of height $2.39 \mathrm{~m}$. Annual average wind speed for the location is $\mathbf{3 . 4 7} \mathbf{m} / \mathbf{s}$. The average monthly speed and wind speed probability of the year is observed, and Hour of peak wind speed occurred at $15 \mathrm{~h}$. Wind speed variation throughout the day is 0.25 (diurnal pattern strength) while the wind randomness is 0.85 (autocorrelation factor). Figure 6.0 gives an overview of wind resource of the selected village.

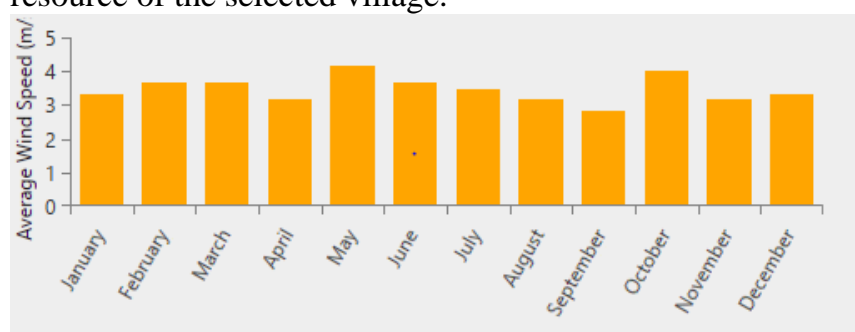

Figure 6.0: Monthly Average Wind Speed for Madangho

\section{A. Village Load Assessment}

For some villages like Madangho, electricity is demanded for small domestic appliances like radio sets, television sets, lights, fans, phone refrigerators etc. and for agricultural and fishing purposes. Major demand is mostly from guest house, health center and agricultural processing and storage facilities. In this study, the load assessment was done by data collection from an existing 400kVA (320kW) CAT D3306 diesel generator. The generator is operated for $12 \mathrm{hrs}$ each day from 7pm-7am by SPDC contractor. Twelve (12) hourly kWh data was collected from the generator's Electronic Management Console (EMC) Panel and converted to $\mathrm{kWh} /$ day. These were collected for three months (92 days) and averaged to $1380 \mathrm{~kW}$. From information gather during the study, Madangho is mostly populated during festive periods, from December - January. This period is considered to require optimum load demand due to the heightened commercial and social activities, thus the peak month was identified as January. Peak load was also recorded to be $189 \mathrm{~kW}$ during the 92 -day data collection. The load profile is show in Figure 7.0 and 8.0 respectively. Figure 9.0 shows scaled data daily load profile. NIMET solar and wind Meteorological data for Madangho-Escravos-Warri is shown in table 2.0

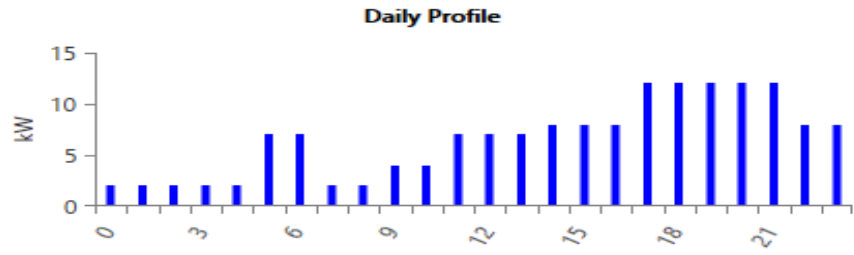

Figure 7.0: Daily Seasonal Load Profile for Madangho

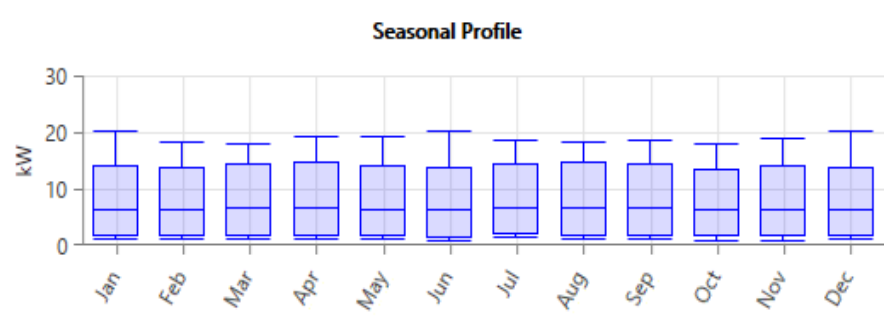

Figure 8.0: Monthly Seasonal Load Profile for Madangho

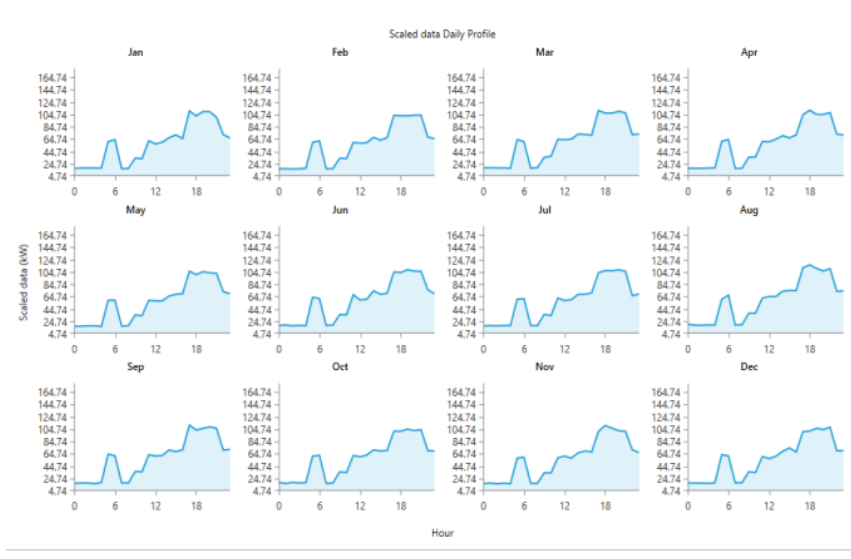

Figure 9.0: Scaled Data Daily Profile

Table 2.0: NIMET - Meteorological Data for Madangho (Escravos -Warri)

\begin{tabular}{|c|c|c|c|c|c|c|c|c|c|c|c|c|c|c|}
\hline ount & (atanent & $\cos \mathrm{n}^{3}$ & atant & catans & chentent & atent & atanes & atents & chenth & chentil & chanli & $6 a^{16}+13$ & (atents & $\sqrt{\text { atrants }}$ \\
\hline & VEAR & & & & & & & & & & & & \multicolumn{2}{|c|}{ MOITHYYAVEGGE } \\
\hline \multirow[t]{2}{*}{ Molith } & 2010 & & 2011 & & 2012 & & 2013 & & 2014 & & 2015 & & & \\
\hline & WIIID & SOAR & Wild & SOLR & Wild & SOLAR & Willo & SOLAR & Willo & SOLAR & Wild & SOLR & WIIID & SOLR \\
\hline AAUAFF & 40 & 5.7 & 40 & 63 & 3.0 & 39 & 3.0 & $\overline{T / A}$ & 3.0 & 29 & 3.0 & 53 & 3,3333 & 48200 \\
\hline FEPOAPY & 50 & 58 & 40 & 56 & 40 & 47 & 4.0 & {$[1 / \mathrm{A}$} & 30 & 43 & 20 & 58 & 3.6067 & 52400 \\
\hline MAPCH & 30 & 45 & 40 & 60 & 4.0 & 41 & 6.0 & $\overline{V I / A}$ & 30 & 51 & 20 & 4.0 & 3.6607 & 4,740 \\
\hline APRIL & 40 & 69 & 29 & 51 & 40 & 5.3 & 3.0 & 5.4 & 30 & 5.7 & 20 & 48 & 3,150 & 55333 \\
\hline WAY & 30 & 5.4 & 60 & 49 & 3.0 & 4.6 & 8.0 & 5.1 & 3.0 & 56 & 20 & 5.4 & 4,167 & 5.667 \\
\hline JUIE & 50 & 3.7 & 40 & 31 & 40 & 3.2 & 4.0 & 3.7 & 30 & 44 & 20 & 29 & 3.6601 & 3500 \\
\hline JUIY & 38 & 41 & 40 & 19 & 40 & 17 & 3.0 & 27 & 3.0 & 26 & 30 & 23 & 3,4667 & 2550 \\
\hline AUGUST & 40 & 31 & 40 & 20 & 30 & 26 & 3.0 & 25 & 20 & 32 & 30 & 09 & 3.167 & 28833 \\
\hline SEPTEMER & 30 & 3.7 & 40 & 27 & 30 & 3.2 & 3.0 & 25 & 20 & 27 & 20 & 0.3 & 28333 & 25567 \\
\hline OCTOEER & 30 & 48 & 40 & 37 & 7.0 & $\sqrt{1 / \mathrm{A}}$ & 3.0 & 46 & 40 & 40 & 30 & 3.4 & 40000 & 4,1000 \\
\hline LIOEVESER & 30 & 58 & 40 & 71 & 3.0 & $\sqrt{1 / \mathrm{A}}$ & 3.0 & 49 & 3.0 & 61 & 30 & 59 & 3.1667 & 59500 \\
\hline DEECEBSER & 40 & 6.7 & 30 & 63 & 30 & $\sqrt{1 / \mathrm{A}}$ & 3.0 & 3.5 & 3.0 & 54 & 40 & 55 & 3,333 & 5,4000 \\
\hline & & & & & & & & & & & & & & \\
\hline HIIVUALAVER & & & & & & & & & & & & & 3,4808 & 43315 \\
\hline
\end{tabular}

Several numbers of simulations for prospective configuration in each design are performed. After which feasibility is carried out and cost analysis for various RE sources are compared. Optimization and sensitivity analysis in terms of resources, technical and economical merits under predefined constraints are carried out. Net Present Cost (NPC), RF and Cost of Electricity (COE) are used to choose the most techno-economic viable DHRES. COE of DHRES compared to COE of DISCOs should present any economic benefit for the designed DHRES.

\section{RESULTS AND ANALYSIS}

This section presents results and analysis of the designed DHRES. Optimization results are presented, followed by 
sensitivity analysis outcome. Environmental and economic aspects are also considered in the analysis. Both sensitivity and optimization results are presented in Figure 10.0. This shows various possible combinations of system component configuration and the techno-economic analysis results.

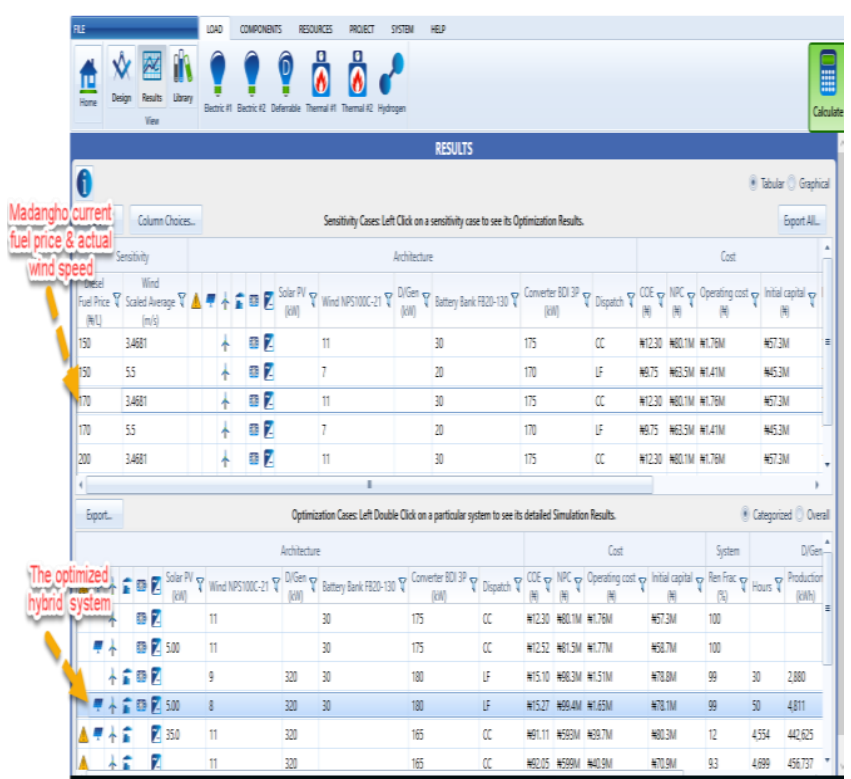

Figure 10.0: HOMER Sensitivity and Optimization Result Screen

\section{A. Optimization Results}

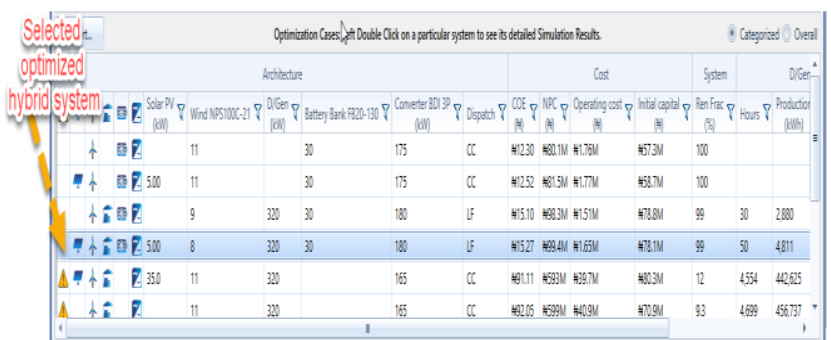

Figure 11.0 HOMER Optimization Result Screen

\section{B. System Architecture}

The optimal DHRES selected from the list of several prospective design configurations that meets Madangho load and system constraints, comprises of $5 \mathrm{~kW}$ array of solar PV, 8 wind turbines $(800 \mathrm{~kW})$, the already existing $320 \mathrm{~kW}$ diesel generator, $180 \mathrm{~kW}$ converter (inverter and rectifier) and 15 strings (2708Ah) batteries. The optimal system as shown in the optimized system architecture in table 3.0 is considered at wind speed of $3.468 \mathrm{~m} / \mathrm{s}$ and diesel price of $\$ 170$, which are the actual present values for both wind speed, and diesel price.

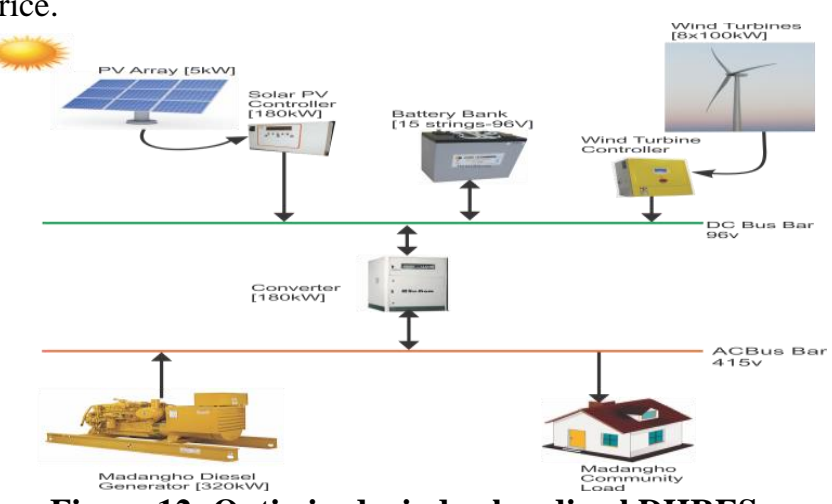

Figure 12: Optimized wind-solar-diesel DHRES
Table 3.0: Optimized System Architecture

\begin{tabular}{|l|l|c|}
\hline System architecture & & $5 \mathrm{~kW}$ \\
\hline PV & Solar PV & 8 \\
\hline Wind Turbine & Wind Turbine & $320 \mathrm{~kW}$ \\
\hline Generator & Madangho Diesel Gen & 15 strings \\
\hline Storage & CELLCUBE@ FB 20-130 & $180 \mathrm{~kW}$ \\
\hline Converter & Leonics MTP4117HP 300KW 480Vdc & \\
\hline Dispatch Strategy & Load Following & \\
\hline
\end{tabular}

\section{Electrical Results}

From the electrical result presented after optimization; wind is the most preferred source of renewable energy with a contribution of 1,214,096 kWh/yr. followed by Solar PV with less than $0.588 \%$ with a contribution of $7,212 \mathrm{kwh} / \mathrm{yr}$. and the Diesel generator contributed $4,811 \mathrm{kWh} / \mathrm{yr}$. which when converted to percentage gives $0.392 \%$ of energy used per year. The fraction of the energy delivered to the village load that originated from renewable sources that is referred to as RF (renewable fraction) is $99.6 \%$, which indicates $0.4 \%$ of energy delivered to the village from diesel generator that is a non-renewable source, therefore minimizing emissions to air.

Table 4.0 Power Generated by Various Components Per Year

\begin{tabular}{|l|r|r|}
\hline Component & Production(kWh/yr) & Fraction (\%) \\
\hline PV & 7,212 & 1 \\
\hline Generator & 4,811 & 0 \\
\hline Wind Turbine & $1,214,096$ & 99 \\
\hline Total & $1,226,119$ & 100 \\
\hline
\end{tabular}

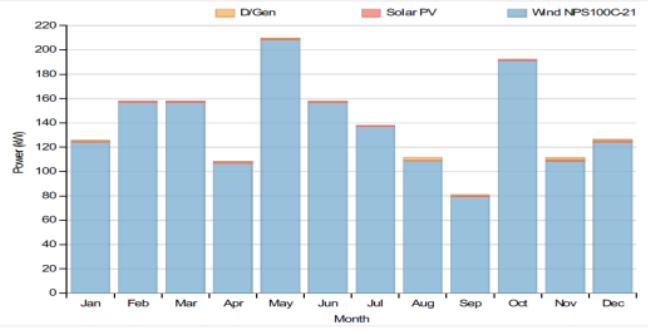

Figure 13: Component bar chart showing power generated annually

The hourly power outputs of solar PV, wind turbine, Madangho diesel generator, battery bank, Converter (rectifier\& inverter) and battery state of charge are shown on the D Map plots in Figures 14 to 19.

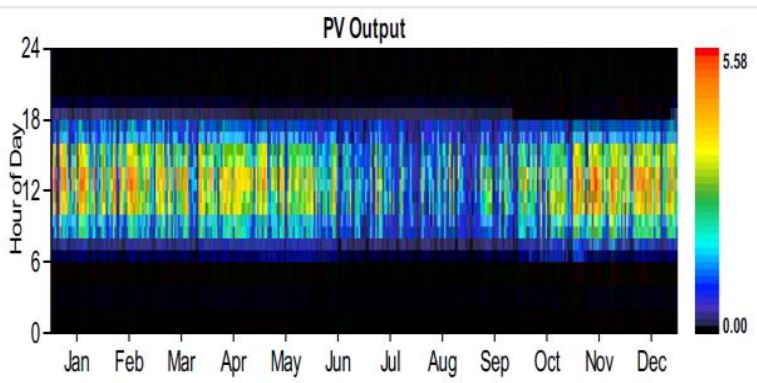

Figure 14: Hourly PV power output per year (DMap) 


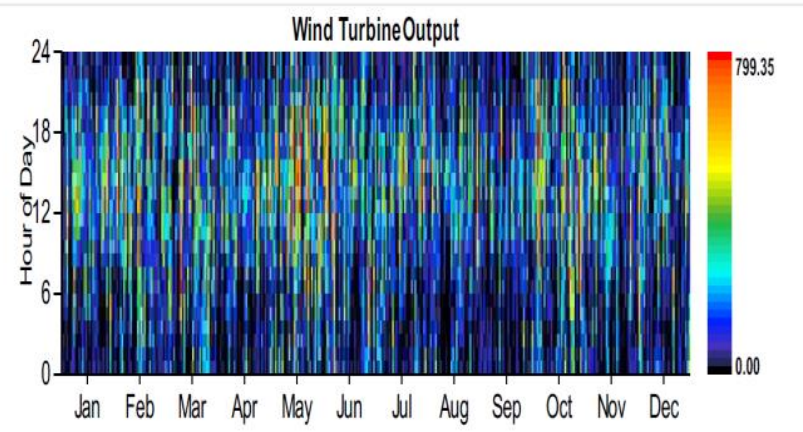

Figure 15: Hourly wind turbine power output per year (DMap)

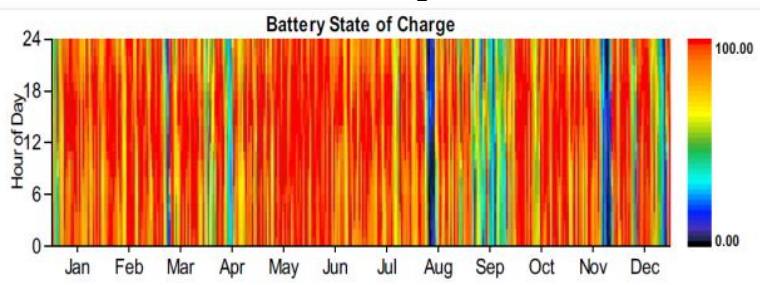

Figure 16: Hourly battery state of charge per year (DMAP)

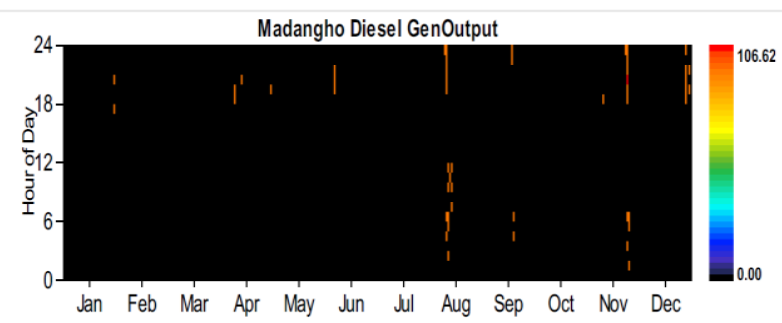

Figure 17: Hourly Madangho diesel generator power output per year (DMap)

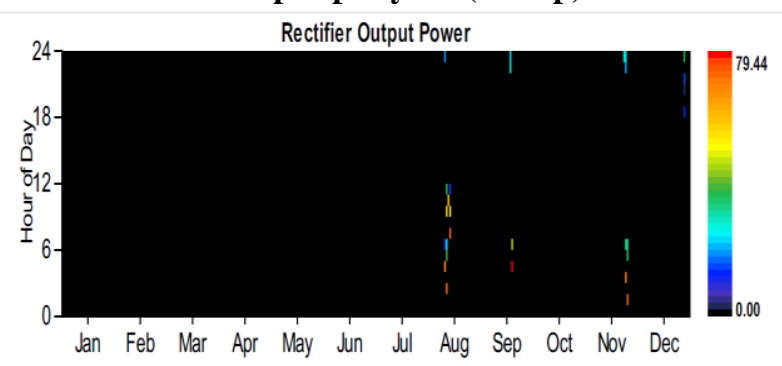

Figure 18: Hourly rectifier power output per year (DMap)

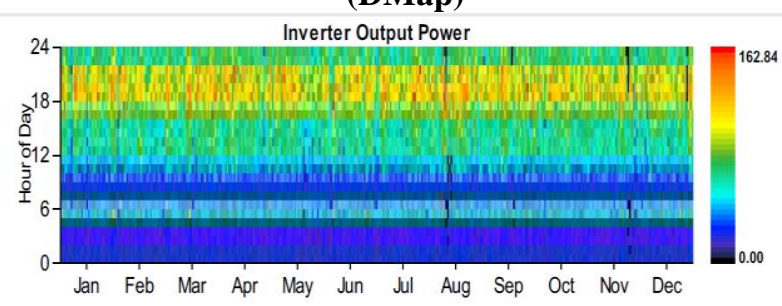

Figure 19: Hourly inverter power output per year (DMap)

\section{Emission}

From the simulation and optimization result, backup diesel generator which is the non-renewable component produces $0.39 \%(1,152 \mathrm{kWh} / \mathrm{yr}$.) of Electricity, consumed $2483 \mathrm{~L} / \mathrm{yr}$ and in service for 50 hours/yr. and with only 32 start/yr. This indicated that $99.61 \%$ of energy generated per year was solely from renewable sources thus saving an enormous amount of harmful emissions to air. The $0.39 \%$ emission per year comprises of $6538 \mathrm{~kg} / \mathrm{yr}$. of carbon dioxide, $16 \mathrm{~kg} / \mathrm{yr}$. carbon monoxide, $2 \mathrm{~kg} / \mathrm{yr}$. un-burnt hydrocarbons, $1 \mathrm{~kg} / \mathrm{yr}$. particulate matter, $13 \mathrm{~kg} / \mathrm{yr}$. sulfur dioxide and $144 \mathrm{~kg} / \mathrm{yr}$. Nitrogen oxide, making a total of $6714 \mathrm{~kg} / \mathrm{yr}$. pollutants. However, if the community were to run on diesel generator only for $24 \mathrm{hrs} /$ day for a year, the total pollutant would be:

$\mathrm{X}=$ Total emission for running diesel gen only

But $0.39 \%$ of $X=6714 \mathrm{~kg} / \mathrm{yr}$. (present emission with DHRES) $\mathrm{X}=(6714 \times 100) / 0.39=1721538.46 \mathrm{~kg} / \mathrm{yr}$.

Therefore, total harmful emission saved using DHRES = $(1721538.46-6714) \mathrm{kg} / \mathrm{yr} .=714824.46 \mathrm{~kg} / \mathrm{yr}$.

Table 5.0 shows emission results obtained

Table 5.0: Emission Results

\begin{tabular}{|l|l|l|}
\hline Emissions & \\
\hline Pollutant & Emissions & Units \\
\hline Carbondioxide & $6538 \mathrm{~kg} / \mathrm{yr}$ \\
\hline Carbon monoxide & $16 \mathrm{~kg} / \mathrm{/r}$ \\
\hline
\end{tabular}

\begin{tabular}{|c|c|c|}
\hline $\begin{array}{l}\text { Pollutant } \\
\text { Unburned hydrocarbons }\end{array}$ & Emissions & 2 Units \\
\hline Particulate matter & & $1 \mathrm{~kg} / \mathrm{yr}$ \\
\hline Suffur dioxide & & $13 \mathrm{~kg} / \mathrm{yr}$ \\
\hline Nitrogen oxides & & $144 \mathrm{~kg} / \mathrm{/r}$ \\
\hline
\end{tabular}

\section{CONCLUSION AND RECOMMENDATION}

The present use of diesel generator to provide electricity to rural communities like Madangho faces enormous logistic challenges making it less cost effective with very high operating cost because of its swampy terrain. This research investigated the techno-economic feasibility of DHRES in a view to providing reliable, cost effective and clean solution for power supply deficiency in Madangho community. The present Caterpillar (CAT) diesel generator is dispatched for only $12 \mathrm{hrs}$ from $1800 \mathrm{hrs}$ to $0700 \mathrm{hrs}$ when the generator is in good working condition. Due to the difficulty of running a single generator with diesel fuel that is not clean, expensive and huge logistic cost, makes the power supply to Madangho community very unstable and unreliable. The insufficient supply of electricity to Madangho community with a population of 2845 impacts negatively on the educational, economic, medical and social services required for the livelihood of any human settlement. In conclusion, the findings after optimization of DHRES indicated that RES are feasible and viable technically and economically in remote communities. RES is readily available and can be harnessed 
by the government or private sectors to provide clean, cheap and reliable electricity supply.

To implement DHRES in similar locations, it required for detail assessment of available renewable sources and requires load demand since DHRES is site specific. However, there is need to under study the environment, culture and the nature of the people before commencing any physical construction in any prospective site. For Niger Delta communities there is immense need for proper stakeholder engagement and proper sensitization to ensure that all stake holders agree before starting the DHRES construction. Though, the simulation and optimization results gave in-depth analysis on the techno-economic feasibility and viability of implementing DHRES, there is need for further studies into the actual technical design in term of the properties of cables, power flow analyses, the thermodynamic and technical efficiency of viable distributed hybrid renewable energy systems. DHRES when implemented will be economical and efficient in providing electricity for both remote rural community and urban city, as the world unfolds into the era of clean power generation from renewable energy resources.

\section{REFERENCES}

[1] Federal Ministry of Power, 2013. INVESTMENT OPPORTUNITIES IN THE NIGERIAN POWER SECTOR. [Online] Available at: http://www.power.gov.ng [Accessed 7 May 2017].

[2] Federal Ministry of power, works and housing, 2017. Daily Operational Report Friday 05/05/2017. [Online] Available at: http://www.pwh.gov.ng/ [Accessed 4 May 2017].

[3] Shaaban, M. \& Petinrin, J., 2014. Renewable Energy Potentials in Nigeria: Meeting rural energy needs. Renewable and Sustainable Energy Reviews, August, Volume 29, pp. 72-84.

[4] Brimmo, A. T., Sodiq, A., Sofela, S. \& Kolo, I., "Sustainable energy development in Nigeria: Wind, hydropower, geothermal and nuclear", (Vol. 1). Renewable and Sustainable Energy Reviews (ELSEVIER), JULY, Volume 74, pp. 474-490, 2017.

[5] Barros, C. P., Ibiowie, A. \& Managic, S., 2014. Nigeria's power sector: Analysis of productivity. Economic Analysis and Policy, February, Volume 44, pp. 65-73.

[6] Huang, R., Low, S. H. \& Ufuk Topcu, K. M. C., 2011. Optimal Design of Hybrid Energy System with PV/Wind Turbine/ Storage: A case Study. Virtual Powr Plants, Distributed Generation, Microgrids, Renewables and Storage (IEEE SmartGridComm), 11(978-1-4577-1702-4), pp. 512-516.

[7] Akinyele, D., Rayudu, R. \& Nair, N, "Life cycle impact assessment of photovoltaic power generation from crystalline silicon-base solr modules in Nigeria", Elsevier Renewable Energy, September, Volume 101, pp. 573-549, 2017.

[8] R.K. Akikur, R.Saidur, H.W.Ping \& K.R.Ullah, 2013. Comparative Study of Stand-Alone and Hybrid Solar Energy Systems Suitable for Off-Grid Rural Electrification: A review. Renewable and Sustainable Energy Reviews (ELSEVIER), June, Volume 27, pp. 738-752.

[9] Shafiullah, G. M. et al., 2010. Economic Analysis of Hybrid Renewable Model for Subtropical Climate. International Journal of Thermal \& Environmental Engineering, 1(2), pp. 57-65.

[10] Brimmo, A. T., Sodiq, A., Sofela, S. \& Kolo, I., 2017. Sustainable energy development in Nigeria: Wind, hydropower, geothermal and nuclear (Vol. 1). Renewable and Sustainable Energy Reviews (ELSEVIER), JULY, Volume 74, pp. 474-490.

[11] Omorogiuwa, E. \& Ekiyor, M. T., 2017. Exploring Technically Feasible and Economically Viable Hybrid Renewable Energy Solution for Off-Grid Electricity Supply. American Journal of Engineering Research (AJER), July, 6(7), pp. 92-105.

[12] Sambo, A. S., 2009. Strategic Developments In Renewable Energy In Nigeria. International Association for Energy Economics |, October.pp. 15-19.

[13] NASA, 2017. NASA Surface meteorology and Solar Energy. [Online] Availableat:https://eosweb.larc.nasa.gov/cgi-bin/sse/sse.cgi?skip@lar c.nasa.gov+s01\#s01

[Accessed 10 July 2017].

[14] Homer Energy, 2016. HOMER® Pro Version 3.7 User Manual, Boulder CO 80301 US:

[15] NIMET, 2017. Nigerian Meteorological Agency. [Online] Available at: http://www.nimet.gov.ng/

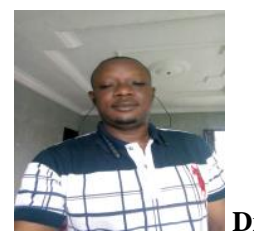
Department of Electrical/Electronic Engineering,Faculty of Engineering,University of Port Harcourt.His research interest is in power systen optimization and renewable energy applications.he is COREN Registered Engineer and a Member of Nigeria Society of Engineer (NSE) 